\title{
DEVELOPMENT OF THE MECHANICAL CULTIVATION-OPERATION FOR SUGAR-BEET CROP
}

\author{
El-Hini, Y. A. ${ }^{(1)}$, Yehia, I. ${ }^{(2)}$, El Lithy, A. M. ${ }^{(3)}$ and Faisal, A. ${ }^{(4)}$
}

ABSTRACT

The aim of this study is to develop the mechanical inter-row cultivation operation for sugar-beet crop at big-scale projects. The investigated parameters were inter-row cultivator forward speed $(4,5,6$ and $7 \mathrm{~km} / \mathrm{h})$, number of shares $(1,2,3)$ and weed intensity (without, low " $<20$ weed $/ m^{2}$ ", moderate "20 - 30 weed $/ \mathrm{m}^{2}$ ", high "30 - 40 weed $/ \mathrm{m}^{2}$ ", and very high "> 40 weed $/ \mathrm{m}^{2}$ "). The main results were: The maximum cultivation-efficiency of $100 \%$ was obtained using forward speed of 4 $\mathrm{km} / \mathrm{h}$, number of shares of 3 and at low weed intensity $\left(<20 \mathrm{weed} / \mathrm{m}^{2}\right)$. Meanwhile, the minimum cultivation-efficiency of $58.7 \%$ was obtained using forward speed of $7 \mathrm{~km} / \mathrm{h}$, number of shares of 1 and at very high weed intensity $\left(>40\right.$ weed $\left./ \mathrm{m}^{2}\right)$. The maximum sugar-beet root yield of 35.5 ton/fed was obtained using forward speed of $4 \mathrm{~km} / \mathrm{h}$, number of shares of 3 and without weed. Meanwhile, the minimum sugar-beet root yield of 22.39 ton/fed was obtained using forward speed of $7 \mathrm{~km} / \mathrm{h}$, number of shares of 1 and at very high weed intensity $\left(>40\right.$ weed $\left./ \mathrm{m}^{2}\right)$.

\section{I-INTRODUCTION}

$\mathrm{I}$ $\mathrm{t}$ is evident that improving agricultural production depends mainly on using improved methods and up-to-date technology through all different agricultural operations. Selection of the appropriate qualitative and quantitative needs concerning agricultural operations of any crop is of great importance to minimize production costs. Sugar beet is considered one of the most important crops, not only for sugar production but also for fodder and organic matter for the soil. It is also considered as a double benefit crop to the farmers, where the roots are processed for sugar production and the green leaves and tops are used for animal feeding. Moreover, beet consumes less water than cane by about two-thirds and it may also grow under a wide variety of soil and climatic conditions.

(1) Prof. Dr., Ag.. Eng., Fac. of Eng., Assuit Univ., (2) Prof. and Head of Mech. Sys. of Ag. Mechanization, Ag. Eng. Res. Inst., (3) Prof. Dr., Ag.. Eng.. Fac. of Ag. Eng., Azhar Univ., Assuit and (4) Eng., Ag. Eng. Res. Inst. 
The cultivated area of sugar beet in Egypt was about 555 thousand feddens yearly producing about 11.981 million $\mathrm{Mg}$ (ton) with an average yield of $21.5 \mathrm{Mg} / \mathrm{fed}(\mathrm{t} / \mathrm{fed})$ according to Bulletin of Estimates Agricultural Income, 2015.

Sugar beet crop is an expensive labor consuming under traditional method. The three main labor-intensive operations of sugar beet production are planting, inter-row cultivation and harvesting. Inter-row cultivation of sugar beet is one of the most critical operations.

Ever since the first cultivation systems were developed for food production farmers of all generations and areas have been faced with the problems of non-crop plants growing amongst the crops. These non-crop plants, which compete with the crops for moisture, light, nutrients and space, have long been known as weeds.

The problems which these non-crop plants have caused to farmers have led to the term weed being used as an insult to other humans, often inferring lack of courage or strength. Yet weeds which are thin, spindly and pale are often so because of their resilience and ability to compete with the crop plants.

Weed management is a strategy that make a desired plant population successful in a particular agro ecosystem using knowledge of the ecology of the undesired plants, that is the weeds (Ghersa et al., 2000). The most effective method of weed management is by making physical contact with the weeds themselves, which is weed control. Currently, there are several ways of controlling weeds, either by using manual, chemical, mechanical or biological means.

The earliest and the simplest weed control method is manual weed control. This method was and is accomplished by a person bending down and using their hands to pull weeds out of the soil. This method then advanced to hand tools, from using a stick to using a hand-hoe. The labor required for weeding is expensive, time consuming and difficult to organize (Weide et al., 2008). Gianessi and Reigner (2007) reported that manual labor costs have increased from $\$ 0.10 /$ hour in 1940 s to $\$ 1.00 /$ hour in 1960 s. As of 2005 , the rate had further increased to $\$ 10 /$ hour. Furthermore, problems such as back pain due to frequent repetitive bending caused manual weed control to be avoided. In areas 
such as California, hoe weeding and hand weeding was banned due to permanent back damage in workers. Before the existence of chemical weed control, mechanical weed control was the best option to solve issues related to manual weeding. In mechanized agriculture, there were times where weeding tools were pulled by draft animals such as buffaloes and horses, which now in the developed world have generally been replaced by tractors. There are various types of mechanical weeding implements in the market that use three 3 main techniques: burying weeds, cutting weeds and uprooting weeds. The burial of weeds through the action of tillage tools, and is usually done during land preparation. For cutting and uprooting weeds, there are two types of machinery available: inter-row cultivators and intra-row cultivators. Inter-row weeding is a weeding method that accomplishes between-planting row weeding, while intra-row does within-planting-row weeding.

Weerasooriya et al. (2016) tested the suitability/adaptability of this new cultivator under the field conditions. It was found that weeding efficiency varied from 69.1 to $89.3 \%$ showing a significantly higher negative relationship with soil bulk density. Further, it gave partial weeding efficiencies for major weed categories such as; $76 \%$ for sedges, $78 \%$ for grasses and $76 \%$ for broad leaves. Plant damaged percentage varied from 1.54 to $13.33 \%$ and did not show any significant relationship with the test field conditions.

Tekade and Dhaliwal (2007) developed a four row rotary weeder to carry out studies on rotary weeding for sugarcane and maize crop. It was found that the field capacity, plant damage, weeding index and fuel consumption varied from 0.062 to $0.214 \mathrm{ha} / \mathrm{h}, 1.56-4.13 \%, 65.54$ $89.96 \%$, 3.26-6.931/ha, $0.039-0.168 \mathrm{ha} / \mathrm{h}, 1.34-3.83 \%, 65.91-90.76 \%$, 2.96-6.921/ha for C \& L types of blades respectively. Field capacity of rotary weeder was $0.077 \mathrm{ha} / \mathrm{h}$ in sugarcane and $0.050 \mathrm{ha} / \mathrm{h}$ in maize as compared to wheel hand hoe $0.035 \mathrm{ha} / \mathrm{h}$ in sugarcane and $0.015 \mathrm{ha} / \mathrm{h}$ in maize.

The objectives of the present investigation are:

1. Developing the inter-row cultivation operation for sugar-beet crop at big-scale projects. 
2. Optimizing some operating parameters for sugar beet inter-row cultivator such as machine forward speed, number of shares and weed intensity.

3. Evaluation the sugar beet production from the economic point of view including the mechanical inter-row cultivation operation.

\section{2- MATERIALS AND METHODS}

\subsection{Materials:}

The main experiments were carried out through successive agricultural شركة ( (أسكندرية للسكر to study Nobaria, El Behira Governorate (النوبارية، محافظة البحيرة) the mechanical operation of inter-row cultivation for sugar beet crop to select the optimum forward speed and number of shares at big-scale projects. The mechanical analysis of the experimental soil was classified as a sandy soil "table 1". The soil mechanical and chemical analyses "table 2" were conducted in the Soil Testing Laboratory, Desert Development Center, and Research Station in Sadat City.

Table 1: Mechanical analysis of the experimental soil.

\begin{tabular}{|c|c|c|c|c|}
\hline \multirow{2}{*}{$\begin{array}{c}\text { Gravels, } \\
\% .\end{array}$} & \multicolumn{3}{|c|}{ Particle size distribution, $\%}$. & \multirow{2}{*}{$\begin{array}{c}\text { Soil } \\
\text { Texture. }\end{array}$} \\
\cline { 2 - 4 } & Sand & Silt & Clay & Sandy \\
\hline 23 & 95.00 & 3.00 & 2.00 & \\
\hline
\end{tabular}

Table 2: Chemical analysis of the experimental soil.

\begin{tabular}{|c|c|c|c|c|}
\hline \multicolumn{5}{|c|}{ Available level of nutrients, ppm. } \\
\hline $\mathrm{P}$ & $\mathrm{K}$ & $\mathrm{Fe}$ & $\mathrm{Zn}$ & $\mathrm{Mn}$ \\
\hline 12.15 & 141.20 & 3.88 & 1.12 & 1.82 \\
\hline $\mathrm{Cu}$ & $\mathrm{Om}, \%$ & $\mathrm{CaCO}_{3}, \%$ & $\mathrm{pH}$ & $\mathrm{EC}, \mathrm{dS} / \mathrm{m}$ \\
\hline 0.97 & 0.22 & 3.59 & 8.48 & 3.72 \\
\hline \multicolumn{5}{|c|}{ Soluble salts, milligram/L } \\
\hline $\mathrm{Ca}$ & $\mathrm{Mg}$ & $\mathrm{Na}$ & $\mathrm{K}$ & $\mathrm{CO}_{3}$ \\
\hline 15.29 & 5.71 & 24.56 & 1.84 & 0.00 \\
\hline $\mathrm{HCO}_{3}$ & $\mathrm{Cl}$ & $\mathrm{SO}_{4}$ & $\mathrm{SAR}$ & $\mathrm{N}$, \\
\hline 9.29 & 23.49 & 11.69 & 8.91 & 714.00 \\
\hline
\end{tabular}

2.1.1. Sugar beet crop: Sugar beet crop "Jostaph" variety, mono-germ seeds were used in this investigation. Number of seeds planted by planter per feddan was 60 thousand (about $1.5-2 \mathrm{~kg} / \mathrm{fed}$ ). Planted-seed spacing intra row of $14.5 \mathrm{~cm}$ and row spacing of $45 \mathrm{~cm}$ was used in this study. 
3.1.2. Tractor: Tractor was used to operate and draw the tested inter-row cultivator. The specifications of this tractor are: Brand name: Fiat, 130-90DT model, rated engine power: $90 \mathrm{~kW}(120 \mathrm{hp})$, PTO speed: $1000 \mathrm{rpm}$, tire recommendation for $45 \mathrm{~cm}$ row spacing, $27 \mathrm{~cm}$ wide, 2 tires on the rear axle and 2 tires on the front axle.

\subsubsection{Equipment:}

(a) Land preparation steps and equipment: Irrigation + Chisel plow (9 shares) two passes + Moldboard plow 4 bottoms.

(b) Planter: French made; sugar beet planter was used in planting the experimental crop. The planter specifications, according to the manufacturer's operating manual, are as follows: brand name: Monosem, model: MECA V4, mounted, No. of rows: 12, rows spacing: $45 \mathrm{~cm}$, width: $610 \mathrm{~cm}$, tested seed-spacing: $14.5 \mathrm{~cm}$, seed size: coated seeds with size of $3.5-4.75 \mathrm{~mm}$ and seed depth of $1.5-2 \mathrm{~cm}$.

(c) Inter-row cultivator: The tested precision inter-row cultivator (Super Crop Company; French made) consists of the parts shown in fig. 1: ( 1) Coulter spring adjustable by crank, (2) Easily adjustable units with pivoting clamps with one single nut, (3) Extra wide clamping no lateral play, (4) Ground clearance under toolbar (65 to $70 \mathrm{~cm}$ ), (5) Stand delivered as standard equipment for easier linkage, (6) Unbeatable sturdiness with the $127 \times 127 \mathrm{~mm}$ toolbar and the solid, heavy duty units, (7) Large parallelogram with individual looking catch for hitching up, (8) Tine brackets in high resistance steel, (9) 32 x 10 flexible tines with foot-duck shares (200 $\mathrm{mm}$ wide), (10) Long units help avoid packing up of earth in the tines, (11) Assembly of 1.2 or 3 foot-duck shares according to working width with share spacing of $20 \mathrm{~cm}$ (maximum cultivation width of $25 \mathrm{~cm}$ ), (12) Protection discs diameter $58 \mathrm{~cm}$ mounted on sealed ball bearings: No obstruction by hub on the plant side of disc, Instantly retractable into upper position with locking catch and Totally, independent so as to avoid stones or other obstacles, (13) Crank for rapid depth control adjustment, (14) Easy rolling depth control wheels (diameter $30 \mathrm{~cm}$ ) very stable (width $10 \mathrm{~cm}$ ): mounted on sealed ball bearing, equipped with self-cleaning tires, (15) Adjustable coulter angle by means of 
screw and (16) Stabilizer disc coulters (2 per machine): retractable, mounted on sealed ball bearing, in constant contact with the groundadjustable spring.

(d) Sprayer: The trailed boom sprayer (Kuhn Blanchard Co., French made, model Atlantique) specifications: boom width: $24 \mathrm{~m}$, sprayer mass: $2200 \mathrm{~kg}$, tank capacity: 3200 Liter, water-cleaning tank: 300 Liter, mixer with $35 \mathrm{~L}$ size for powder and liquid chemicals, hydraulic agitator and pump: piston type of 15 bar with capacity $250 \mathrm{~L}$.

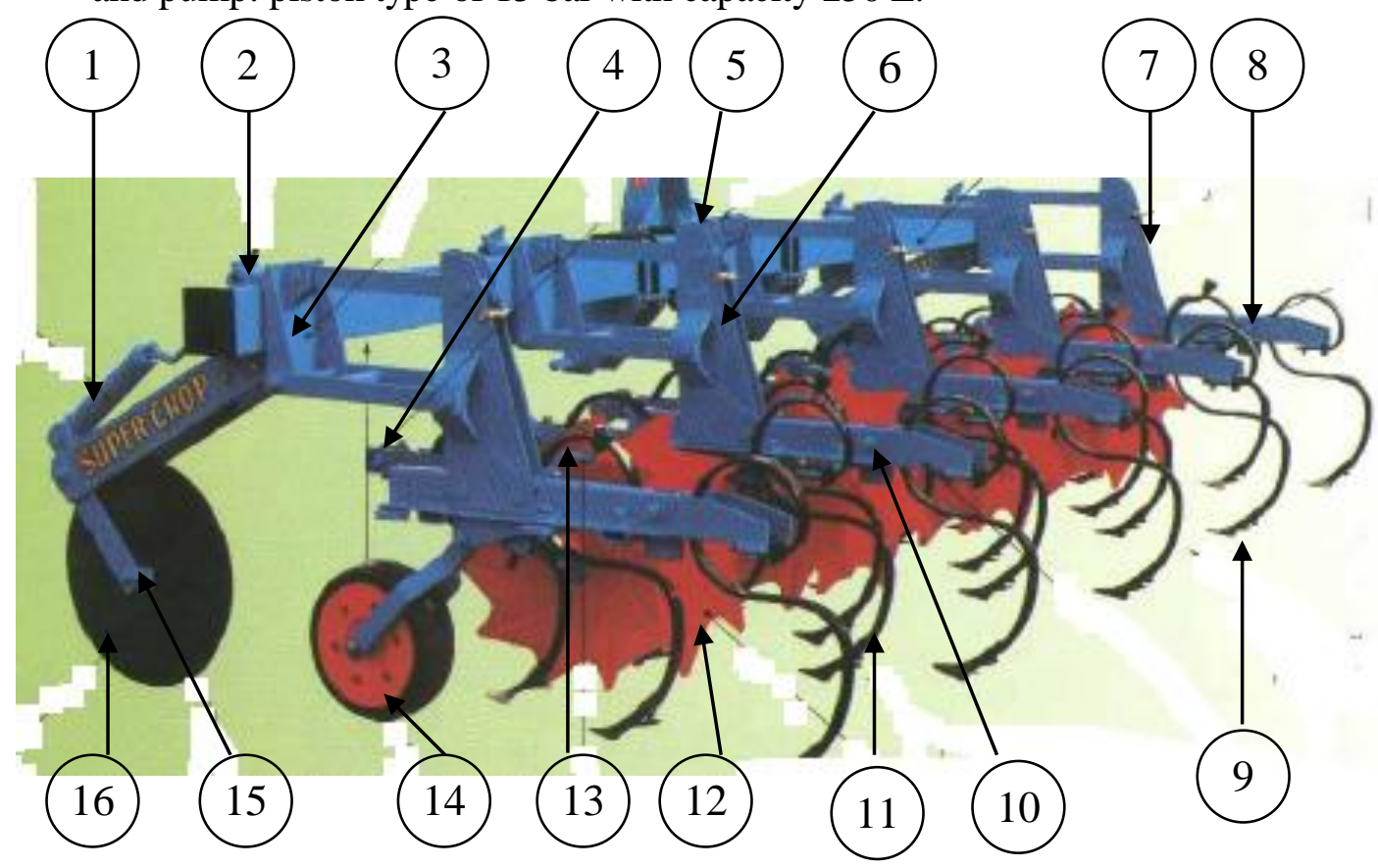

Fig. 1: The tested precision inter-row cultivator.

(1) Coulter spring adjustable by crank, (2) Easily adjustable units, (3) Extra wide clamping no lateral play, (4) Good ground clearance under toolbar, (5) Stand delivered as standard equipment for easier linkage, (6) Unbeaten sturdiness, (7) Large parallelogram with individual looking catch for hitching up, (8) Tine brackets, (9) Flexible tines with foot-duck shares, (10) Long units help avoid packing up of earth in the tines, (11) Assembly of the tine, (12) Protection discs mounted on sealed ball bearings: (13) Crank for rapid depth control adjustment, (14) Easy rolling depth control wheels: (15) Adjustable coulter angle by means of screw and (16) Stabilizer disc coulters. 
(e) Center pivot irrigation specifications: Center pivot specifications were: 8" PVT point, 7 spans x 180 feet length 6 5/8" dia., over hang of $18 \mathrm{~m}$ length and $65 / 8$ " diameter, total length of $389 \mathrm{~m}$ and wetted area of 47 ha.

\section{2-2 Methods:}

\subsubsection{Investigated parameters:}

(1) Forward speeds: four forward-speeds of 4, 5, 6 and $7 \mathrm{~km} / \mathrm{h}$ were tested.

(2) Number of shares: three numbers of shares of 1, 2 and 3 were tested. Fig. 2 shows the arrangement of cultivation duck-foot shares in cultivation area. Also, the same figure shows the tested row-spacing, intra-row spacing (plant spacing in the same row), and number of shares, share width and safety-band width.

(3) Weed intensity: without weed, low $\left(<20 \mathrm{weed} / \mathrm{m}^{2}\right)$, moderate $(20-30$ weed $\left./ \mathrm{m}^{2}\right)$, high $\left(30-40 \mathrm{weed} / \mathrm{m}^{2}\right)$ and very high $\left(>40 \mathrm{weed} / \mathrm{m}^{2}\right)$ weed intensities were tested.

\subsubsection{Measurements:}

(a) Soil mechanical and chemical-analysis: Seven random samples were taken to determine soil mechanical and chemical analysis using the hydrometer method.

(b) Cultivation efficiency: Cultivation efficiency using inter-row cultivator was calculated according to the following equation:

$$
\eta c=\frac{\mathrm{Wa}}{W b} \times 100
$$

Where: $\eta c$ : Cultivation efficiency by inter-row cultivator, $\%$, $\mathrm{Wb}=$ Number of weeds in the cultivation area before cultivation and $\mathrm{Wa}=$ Number of weeds in the cultivation area after cultivation.

(c) Sugar-beet plant damage percent: Mechanical damage of sugar-beet plants using inter-row cultivator was calculated according to the following equation:

$$
M D=\frac{\mathrm{Nd}}{N t} \times 100
$$

Where: MD: mechanical damage of sugar-beet plants using inter-row cultivator "\%", $\mathrm{Nt}=$ total number of sugar-beet plants and $\mathrm{Nd}=$ Number of damaged sugar-beet plants caused by inter-row cultivator. 
(d) Effective field capacity: Four speeds were used during the field experiments. Times were recorded for the following operations: cultivation; turning; and adjusting to calculate field capacity by using the equation.

$$
\text { F.C } \text { ef }_{\text {fotal time }}=\frac{60}{\text { fed./h }}
$$

Where: $F \cdot C_{\text {ef }}=$ Effective field-capacity, "fed/h" and

Total time, "min/fed" = cultivation time + turning time + adjusting time
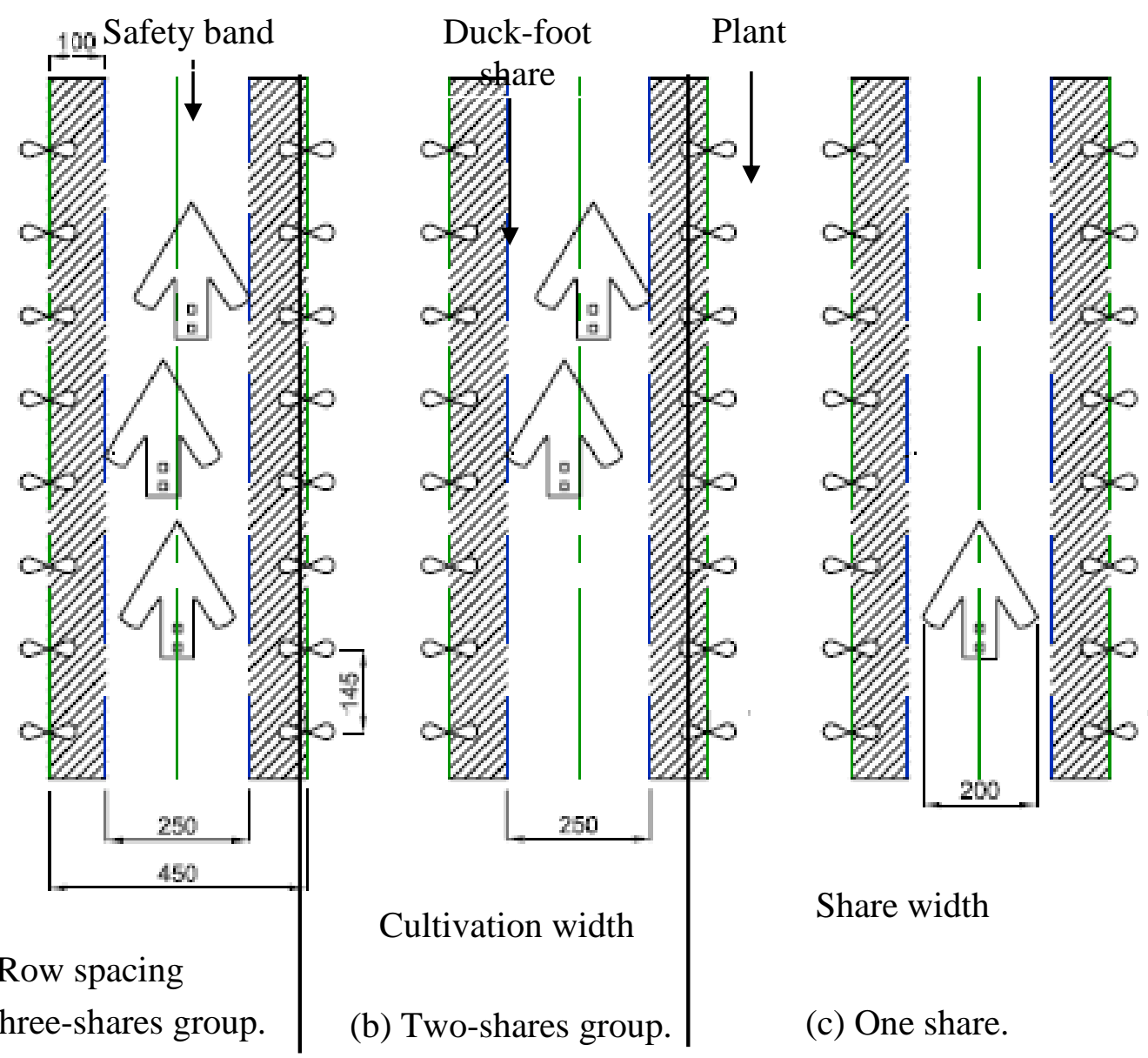

Share width

(c) One share.

Dims. in $\mathrm{mm}$.

Fig. 2: Tested row spacing, intra-row spacing (plant spacing in the same row), number of shares, share width and safety-band width. 
(e) Field efficiency: Field efficiency was calculated using the following equation:

$$
\eta_{\mathrm{f}}=\frac{\text { F.C. }_{\text {act. }}}{\text { F.C. }_{\text {th. }}} \times 100 \%
$$

Where: $\eta_{\mathrm{f}}=$ Filed efficiency, \%, F.C.act. $=$ Effective field-capacity, fed./h and F.C.th. $=$ Theoretical field-capacity, fed./h.

(f) Root yield: The yield $\left(\mathrm{R}_{\mathrm{Y}}\right)$ of the roots was determined using the following equation (Taieb, 1997) was used:

$$
R_{\mathrm{Y}}(\text { ton } / \text { fed })=\frac{\mathrm{M} \times 4200}{\mathrm{~A} \times 1000}
$$

Where: $\mathrm{M}=$ mass of lifted root "kg" and A = harvested area " $\mathrm{m}^{2}$ ".

(g) Fuel consumption: Fuel consumption was recorded by accurately measuring the decrease in fuel level in the fuel tank immediately after executing each operation of 15 minutes.

(h) Required power: Required fuel-power was estimated by using the following formula (Hunt, 1983):

$$
\begin{aligned}
P & =F_{c} \times F_{d} \times\left(\frac{1}{3600}\right) \times C . V . \times 4270 \times \eta_{t h} \times \eta_{m} \\
\mathrm{P} & =3.23 \mathrm{~F}_{\mathrm{c}}
\end{aligned}
$$

Where: $\mathrm{P}=$ required power " $\mathrm{kW}$ ", $\mathrm{F}_{\mathrm{c}}=$ fuel consumption ' $\mathrm{L} / \mathrm{h}$ ", $F_{d}=$ density of fuel " $\mathrm{kg} / \mathrm{L}$ " ( $=0.85$ for diesel fuel $)$,

C.V. = calorific value of fuel " $\mathrm{kcal} / \mathrm{kg} "=10^{4}$ for diesel fuel, $\eta_{\text {th }}=$ Thermal efficiency of fuel, it is assumed about $35 \%$ for diesel engine and $\eta_{\mathrm{m}}=$ Mechanical efficiency of fuel, it is assumed about $80 \%$ for diesel engine.

(i) Specific energy: Specific energy can be calculated by using the following equation:

$$
\text { Specific energy }(k W . h / f e d .)=\frac{\text { Re quired power }(k W)}{\text { Actual field capacity }(\text { fed } . / h)}
$$

(i) Cost analysis: The operational cost by Egyptian pound per feddan was calculated according to leasing of field, equipment, irrigation, seeds, chemicals, fertilizers and labors salary.

Cost per unit of production can be determined using the following equation: 
Cost per unit of production $(\mathrm{L.E} . / \mathrm{Mg})=\frac{\text { Operational } \cos t(\mathrm{~L} . \mathrm{E} . / \mathrm{fed} .)}{\text { Root yield }(\mathrm{Mg} / \mathrm{fed})}--$

\section{3- RESULTS AND DISCUSSION}

\section{3-1 Effect of forward speed, number of shares and weed intensity on cultivation efficiency.}

Figs. 3 and 4 show the effect of forward speed, number shares and weed intensity on cultivation efficiency.

The maximum cultivation-efficiency of $100 \%$ was obtained at forward speed of $4 \mathrm{~km} / \mathrm{h}$, number of shares of 3 and at low weed intensity $(<20$ weed $/ \mathrm{m}^{2}$ ). Meanwhile, the minimum cultivation-efficiency of $58.7 \%$ was obtained at forward speed of $7 \mathrm{~km} / \mathrm{h}$, number of shares of 1 and at very high weed intensity $\left(>40 \mathrm{weed} / \mathrm{m}^{2}\right)$.

\section{(a) Effect of forward speed.}

By increasing forward speed from 4 to $7 \mathrm{~km} / \mathrm{h}$ the cultivation efficiency decreased by $25.13 \%$ at all tested number of shares and weed intensities. The decreasing of cultivation efficiency by increasing forward speed is due to decrease in the cultivation depth. The decreasing of cultivation depth does not uproot the weeds by duck-foot shares.

\section{(b) Effect of number of shares.}

By increasing number of shares from 1 to 2 the cultivation efficiency increased by $10.18 \%$ at all tested forward-speeds and weed intensities. By increasing number of shares from 1 to 3 the cultivation efficiency increased by $15.93 \%$ at all tested forward-speeds and weed intensities.

The increasing of cultivation efficiency by increasing number of shares is due to increasing the cultivation width.

\section{(c) Effect of weed intensity.}

Cultivation-efficiency ranges 68.2 - 100, 62.8 - 99.2, 61.5 98.1, 58.7 $95.3 \%$ were at low $\left(<20\right.$ weed $\left./ \mathrm{m}^{2}\right)$, moderate $\left(20-30\right.$ weed $\left./ \mathrm{m}^{2}\right)$, high $\left(30-40 \mathrm{weed} / \mathrm{m}^{2}\right)$ and very high $\left(>40 \mathrm{weed} / \mathrm{m}^{2}\right)$ respectively and all tested forward-speeds and number of shares.

The increasing of cultivation efficiency by decreasing weed intensity is due to increasing sugar-beet plants growing. 
Forward speed, km/h.

口4 口5 $\mathbf{6} 67$

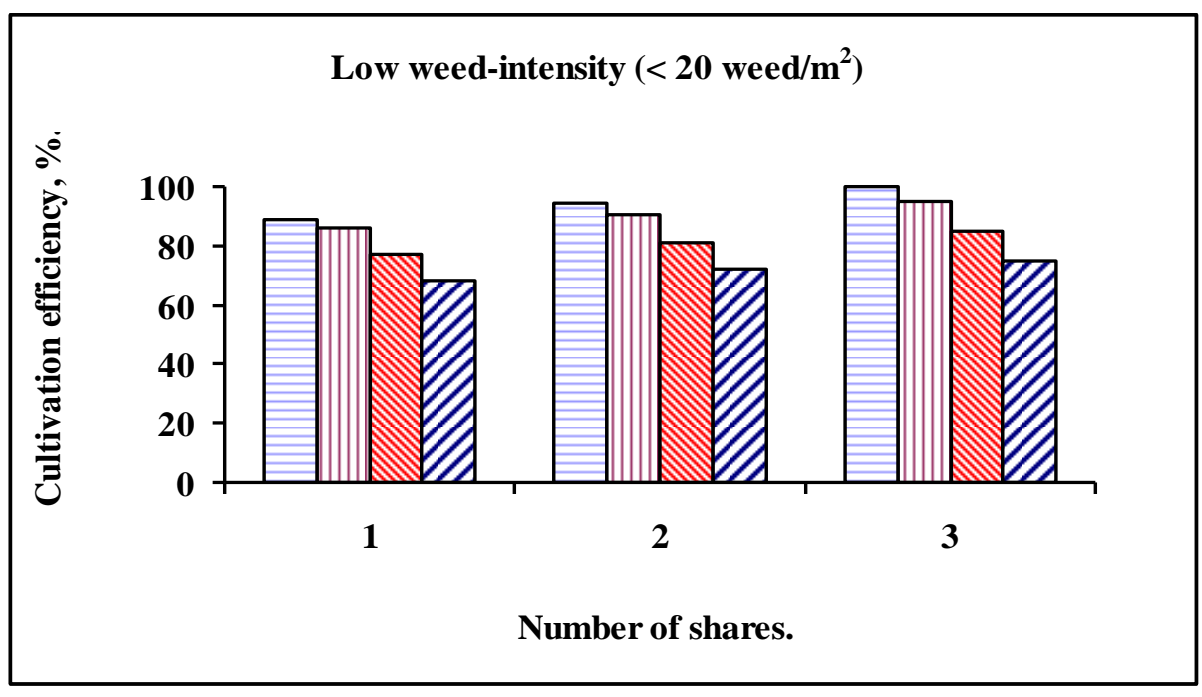

Forward speed, km/h.

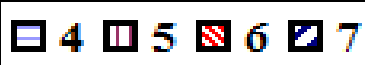

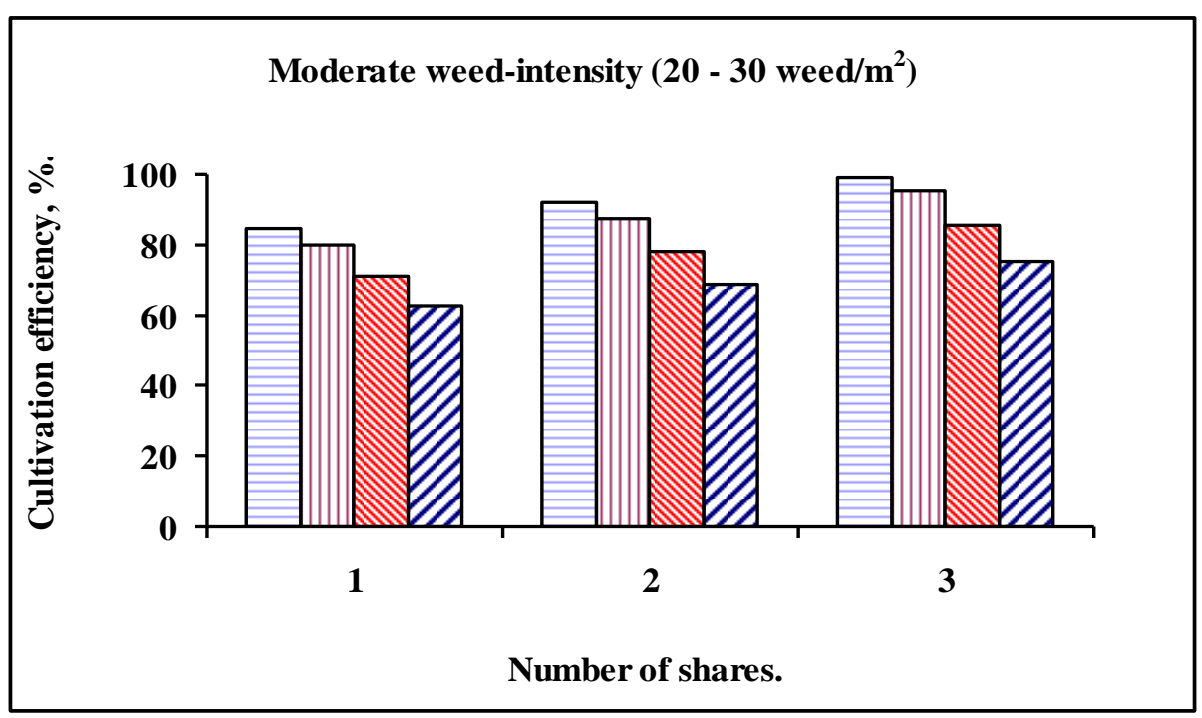

Fig. 3: Effect of forward speed, number shares on cultivation efficiency at low and moderate weed intensities. 

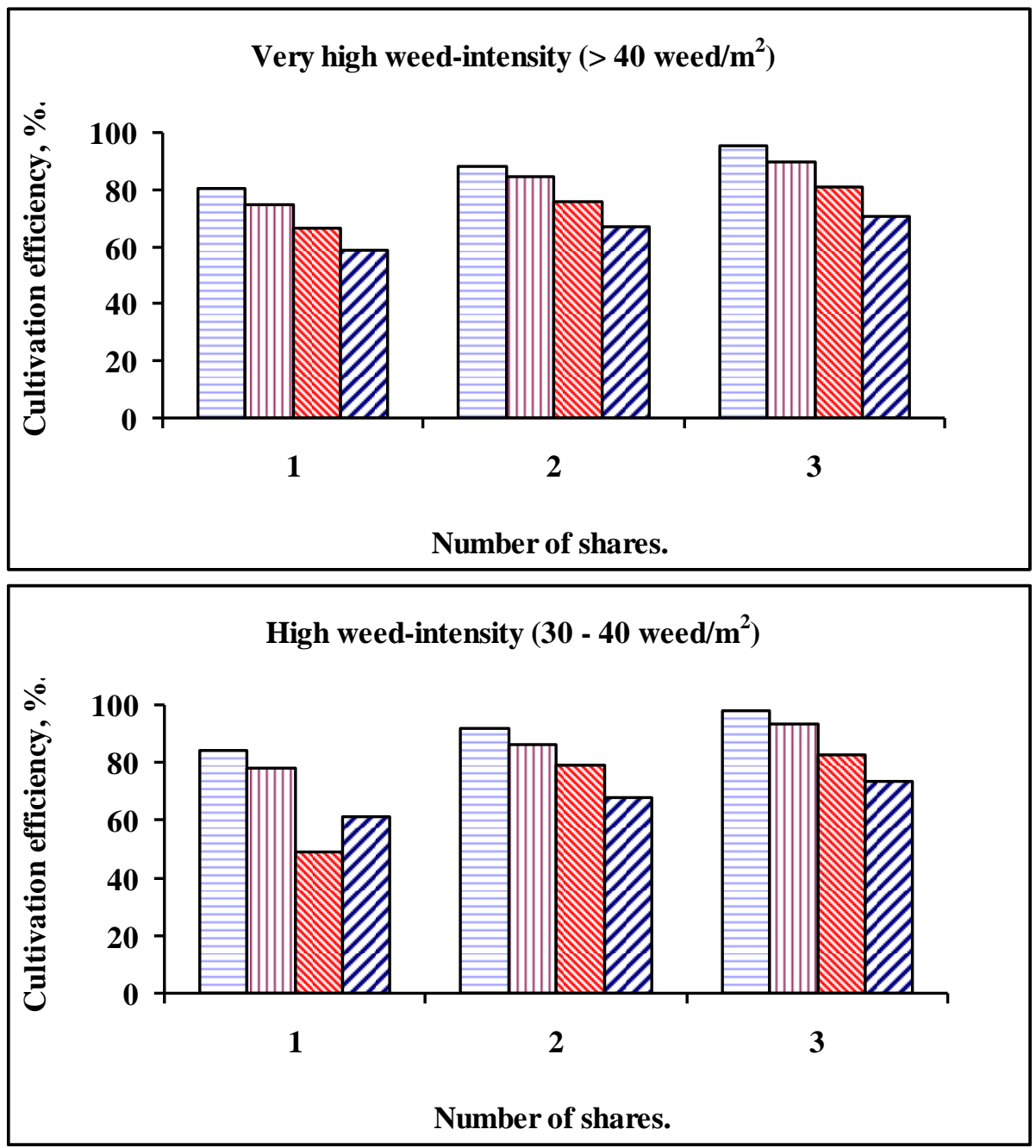

Fig. 4: Effect of forward speed, number shares on cultivation efficiency at high and very high weed intensities.

\section{4-2 Effect of forward speed and number of shares on sugar-beet plant damage percent.}

Fig. 5 shows the effect of forward speed and number shares on sugar-beet plant damage percent.

The maximum sugar-beet plant damage percent of $5.6 \%$ was obtained at forward speed of $7 \mathrm{~km} / \mathrm{h}$ and number of shares of 3 . Meanwhile, the minimum sugar-beet plant damage percent of $0.69 \%$ was obtained at forward speed of $4 \mathrm{~km} / \mathrm{h}$ and number of shares of 1 . 


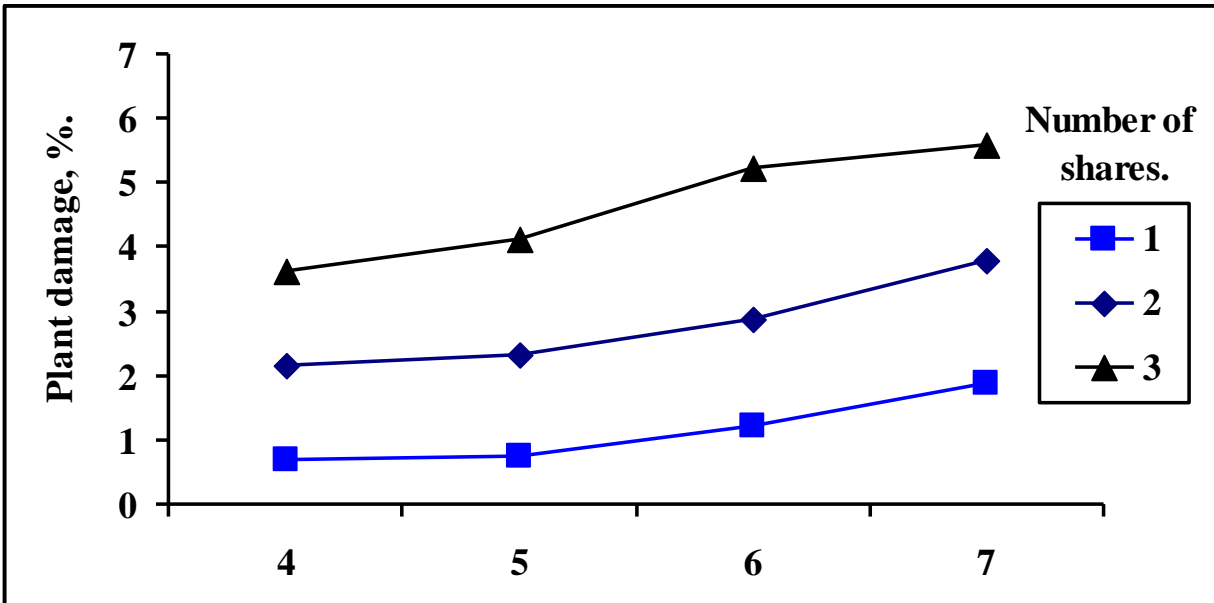

Forward speed, km/h.

Fig. 5: Effect of forward speed, number shares on sugar-beet plant damage.

The increasing of sugar-beet plant damage by increasing forward speed is due to increasing the vibration of inter-row cultivator in the direction perpendicular to direction of motion. Meanwhile, the increasing of sugarbeet plant damage by increasing number of shares is due to increasing the cultivation width which increases the chance of contact of the shares with the sugar-beet plants.

\section{3-1 Effect of forward speed, number of shares and weed intensity on sugar- beet root yield.}

Figs. 6 and 7 show the effect of forward speed, number shares and weed intensity on sugar-beet root yield.

The maximum sugar-beet root yield of 35.5 ton/fed was obtained at forward speed of $4 \mathrm{~km} / \mathrm{h}$, number of shares of 3 and without weed. Meanwhile, the minimum sugar-beet root yield of 22.39 ton/fed was obtained at forward speed of $7 \mathrm{~km} / \mathrm{h}$, number of shares of 1 and at very high weed intensity (> 40 weed $\left./ \mathrm{m}^{2}\right)$.

(a) Effect of forward speed.

By increasing forward speed from 4 to $7 \mathrm{~km} / \mathrm{h}$ the sugar-beet root yield decreased by $15.31 \%$ at all tested number of shares and weed intensities. The decreasing of sugar-beet root yield by increasing forward speed is due to decreasing the cultivation efficiency and increasing of plant damage. 
Forward speed. km/h.

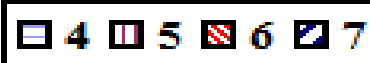

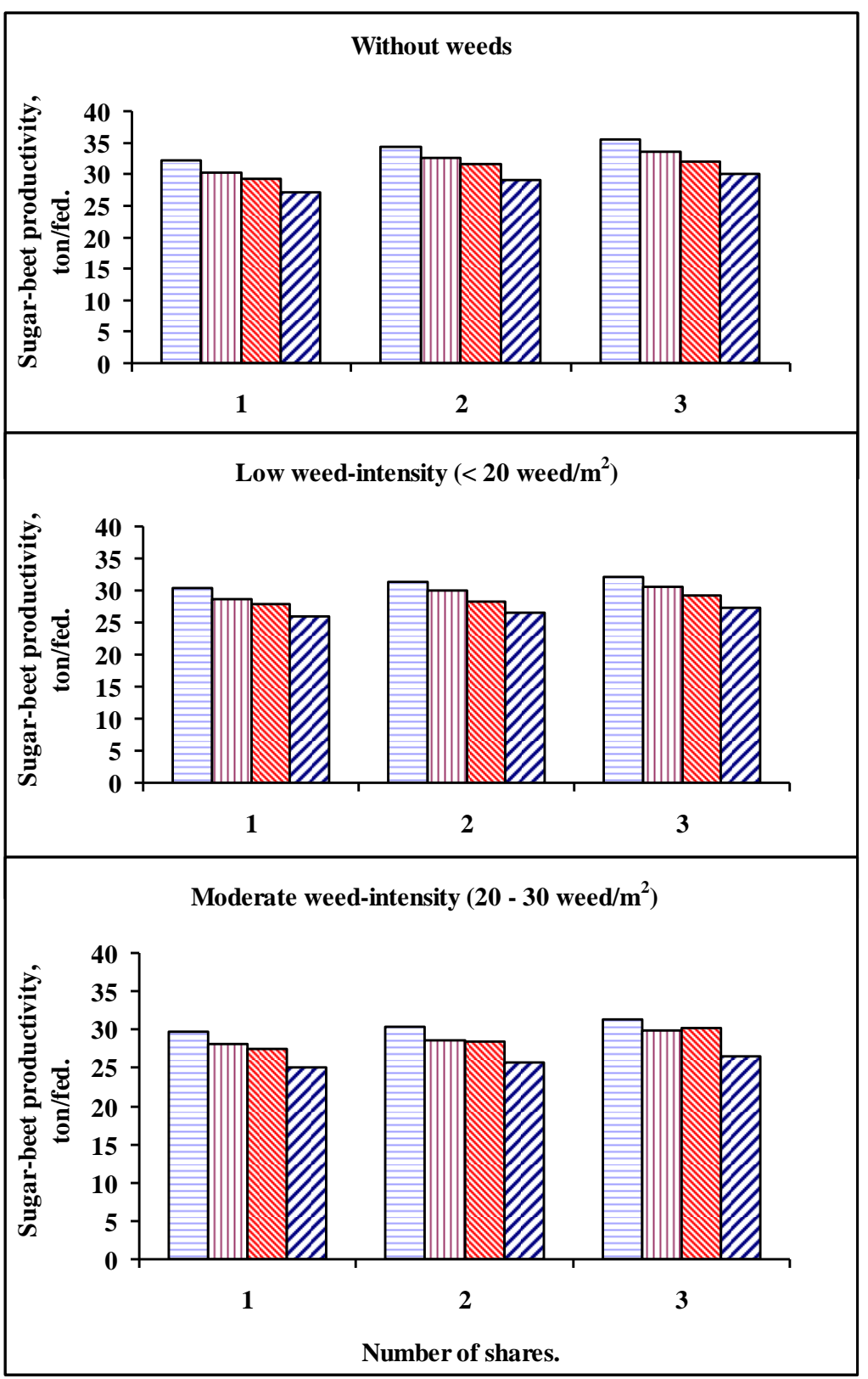

Fig. 6: Effect of forward speed, number shares on sugar-beet productivity without weed, at low and moderate weed intensity. 
Forward speed, $\mathbf{k m} / \mathbf{h}$.

묻6ㅁ
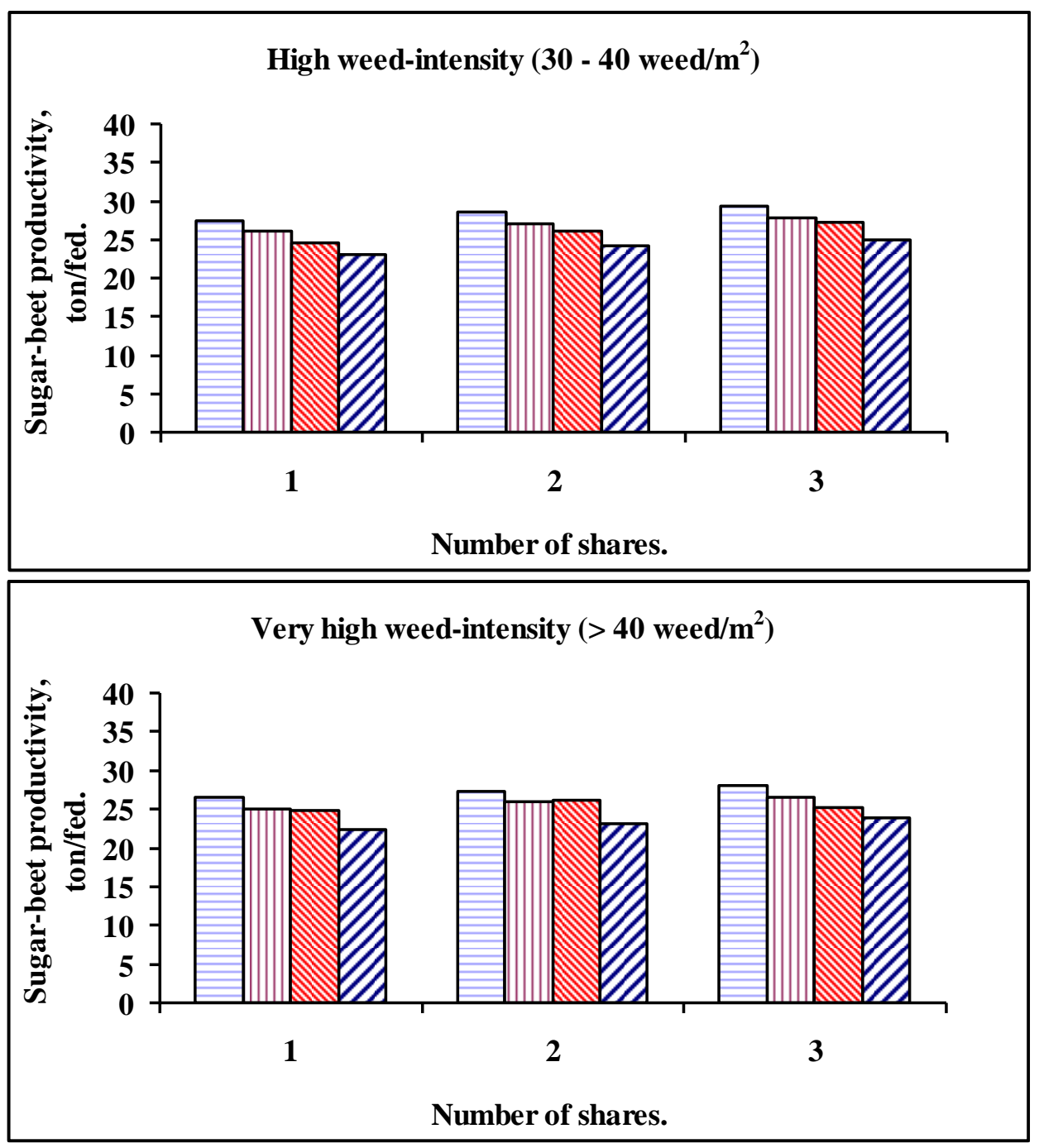

Fig. 7: Effect of forward speed, number shares on sugar-beet yield at high and very high weed intensity.

(b) Effect of number of shares.

By increasing number of shares from 1 to 2 the sugar-beet root yield increased by $4.15 \%$ at all tested forward-speeds and weed intensities. 
By increasing number of shares from 1 to 3 the sugar-beet root yield increased by $6.78 \%$ at all tested forward-speeds and weed intensities.

The increasing of sugar-beet root yield by increasing number of shares is due to increasing the cultivation efficiency and decreasing plant damage.

(c) Effect of weed intensity.

Sugar-beet root yield ranges 27.21 - 35.5, $25.91-32.2,25.1$ - 31.4, $23.13-29.4$ and $22.39-28.1$ ton/fed were for without weed, low $(<20$ weed $\left./ \mathrm{m}^{2}\right)$, moderate $\left(20-30\right.$ weed $\left./ \mathrm{m}^{2}\right)$, high $\left(30-40 \mathrm{weed} / \mathrm{m}^{2}\right)$ and very high (> 40 weed $/ \mathrm{m}^{2}$ ) respectively and all tested forward-speeds and number of shares.

The increasing of sugar-beet root yield by decreasing weed intensity is due to increasing the sugar-beet plants growing because of decreasing the competition between weeds and sugar-beet plants.

\section{3-4 Effect of forward speed and number of shares on specific energy.}

Fig. 8 shows the effect of forward speed and number shares on specific energy.

The maximum specific energy of $12.5 \mathrm{~kW} . \mathrm{h} / \mathrm{fed}$ was obtained at forward speed of $4 \mathrm{~km} / \mathrm{h}$ and number of shares of 3 . Meanwhile, the minimum specific energy of $7.7 \mathrm{~kW} . \mathrm{h} /$ fed was obtained at forward speed of $7 \mathrm{~km} / \mathrm{h}$ and number of shares of 1 .

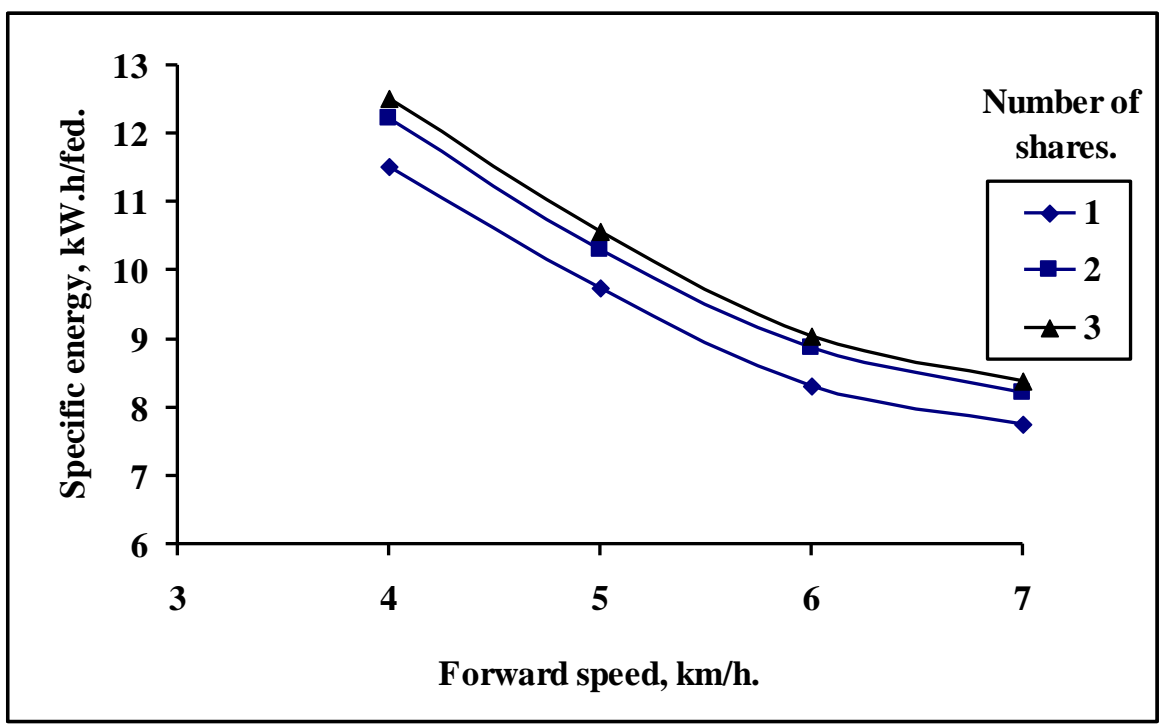

Fig. 8: Effect of forward speed and number of shares on specific energy. 


\section{3-5 Effect of forward speed on effective field-capacity and field efficiency.}

Fig. 9 shows the effect of forward speed and number shares on effective field-capacity and field efficiency of inter-row cultivator.

The maximum effective field-capacity of $8.71 \mathrm{fed} / \mathrm{h}$ was obtained at forward speed of $7 \mathrm{~km} / \mathrm{h}$. Meanwhile, the minimum effective fieldcapacity of $5.04 \mathrm{fed} / \mathrm{h}$ was obtained at forward speed of $4 \mathrm{~km} / \mathrm{h}$.

The maximum field efficiency of $90.5 \%$ was obtained at forward speed of $4 \mathrm{~km} / \mathrm{h}$. Meanwhile, the minimum field efficiency of $84.3 \%$ was obtained at forward speed of $7 \mathrm{~km} / \mathrm{h}$.

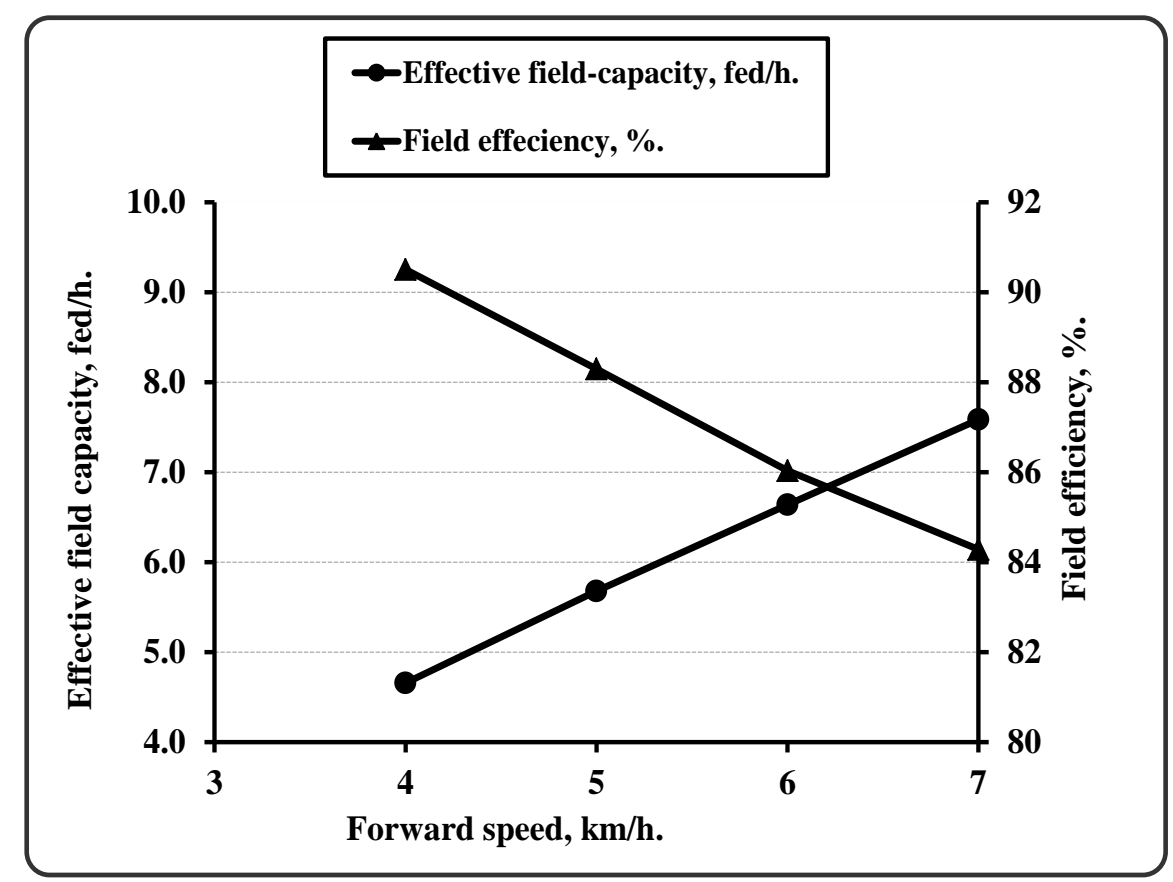

Fig. 9: Effect of forward speed on effective field-capacity and field efficiency of inter-row cultivator.

3-6 Effect of number of shares and weed intensity on operation and production costs.

Table 3 shows that the real costs for sugar beet production was 11589 L.E./fed. Meanwhile, the sugar beet production cost with company subsidize was 10201 L.E./fed. 
Table 3: Production costs "L.E./fed" for sugar beet.

\begin{tabular}{|l|c|c|}
\hline \multirow{2}{*}{\multicolumn{1}{|c|}{ Items }} & \multicolumn{2}{c|}{ Production costs, L.E./fed. } \\
\cline { 2 - 3 } & Real & With company subsidize \\
\hline Lease & 5000 & 5000 \\
\hline Seeds & 1728 & 720 \\
\hline Labor & 300 & 300 \\
\hline Fertilizers & 2326 & 2326 \\
\hline Chemicals & 610 & 610 \\
\hline Land preparation & 80 & 80 \\
\hline Spreader & 75 & 75 \\
\hline Sprayer & 90 & 90 \\
\hline Leveling machine & 60 & \\
\hline Planter & 100 & 1000 \\
\hline Inter row cultivator & 60 & \\
\hline Harvesting & 1100 & \\
\hline Loading & 60 & \\
\hline Total cost & 11589 & 10201 \\
\hline \hline
\end{tabular}

Table 4 shows the effect of forward speed and number of shares on production costs and net profit at optimum inter-row cultivator forward speed of $4 \mathrm{~km} / \mathrm{h}$.

The maximum production costs of 317, 337, 343, 372 and 385 L.E./ton were obtained without weed, low, moderate, high and very high weedintensity respectively and using forward speed of $4 \mathrm{~km} / \mathrm{h}$ and number of shares of 1. Meanwhile, the minimum production-costs of 287, 317, 325, 347 and 363 L.E./ton were obtained without weed, low, moderate, high and very high weed-intensity respectively and using forward speed of 4 $\mathrm{km} / \mathrm{h}$ and number of shares of 3 .

The maximum profits of 5774, 4289, 3929, 3029 and 2444 L.E./fed were obtained without weed, low, moderate, high and very high weed-intensity respectively and using forward speed of $4 \mathrm{~km} / \mathrm{h}$ and number of shares of 3 . Meanwhile, the minimum profits of 4289, 3434, 3164, 2129 and 1724L.E./fed were obtained without weed, low, moderate, high and very high weed-intensity respectively and using forward speed of $4 \mathrm{~km} / \mathrm{h}$ and number of shares of 1 . 
Table 4: Production costs and net profits using optimum inter-row cultivator speed of $4 \mathrm{~km} / \mathrm{h}$ at different numbers of shares.

\begin{tabular}{|c|c|c|c|c|c|c|}
\hline $\begin{array}{c}\text { Weed } \\
\text { density }\end{array}$ & $\begin{array}{l}\text { Number of } \\
\text { share }\end{array}$ & $\begin{array}{c}\text { Yield, } \\
\text { Ton/fed } \\
.\end{array}$ & $\begin{array}{l}\text { Production } \\
\text { cost, L.E./fed. }\end{array}$ & $\begin{array}{l}\text { Production } \\
\text { cost, } \\
\text { L.E./ton. }\end{array}$ & $\begin{array}{c}\text { Total } \\
\text { income, } \\
\text { L.E./fed. }\end{array}$ & $\begin{array}{l}\text { Net profit, } \\
\text { L.E./fed }\end{array}$ \\
\hline \multirow{3}{*}{$\begin{array}{l}\text { Without } \\
\text { weed }\end{array}$} & 1 & 32.2 & \multirow{15}{*}{$\begin{array}{c}10201 \\
\text { (with company subsidize) }\end{array}$} & 317 & 14490 & 4289 \\
\hline & 2 & 34.4 & & 297 & 15480 & 5279 \\
\hline & 3 & 35.5 & & 287 & 15975 & 5774 \\
\hline \multirow{3}{*}{$\begin{array}{c}\text { Low } \\
<20 \text { weed } / \mathrm{m}^{2}\end{array}$} & 1 & 30.3 & & 337 & 13635 & 3434 \\
\hline & 2 & 31.4 & & 325 & 14130 & 3929 \\
\hline & 3 & 32.2 & & 317 & 14490 & 4289 \\
\hline \multirow{3}{*}{$\begin{array}{c}\text { Moderate } \\
20-\mathbf{3 0} \text { weed } / \mathrm{m}^{2}\end{array}$} & 1 & 29.7 & & 343 & 13365 & 3164 \\
\hline & 2 & 30.3 & & 337 & 13635 & 3434 \\
\hline & 3 & 31.4 & & 325 & 14130 & 3929 \\
\hline \multirow{6}{*}{$\begin{array}{l}\text { Very high } \\
>40 \mathrm{weed} / \mathrm{m}^{2}\end{array}$} & 1 & 27.4 & & 372 & 12330 & 2129 \\
\hline & 2 & 28.6 & & 357 & 12870 & 2669 \\
\hline & 3 & 29.4 & & 347 & 13230 & 3029 \\
\hline & 1 & 26.5 & & 385 & 11925 & 1724 \\
\hline & 2 & 27.3 & & 374 & 12285 & 2084 \\
\hline & 3 & 28.1 & & 363 & 12645 & 2444 \\
\hline
\end{tabular}

Sugar-beet roots price $=450$ L.E./ton.

\section{4- CONCLUSION}

It is concluded that using the tested inter-row cultivator with forward speed of $4 \mathrm{~km} / \mathrm{h}$ and number of shares of three which gave the cultivation efficiencies of 100, 100, 99.2, 98.1 and $95.3 \%$, plant damage of $0.69 \%$, sugar-beet yields of 35.5, 32.2, 31.4, 29.4 and 28.1 ton/fed, specific energy of $12.5 \mathrm{~kW} . \mathrm{h} / \mathrm{ton}$, production costs of $317,325,347363 \mathrm{~L} . \mathrm{E} . / \mathrm{ton}$, and net profits of 4289, 3929, 3029 and 2444 L.E./fed at weed intensities of low $\left(<20 \mathrm{weed} / \mathrm{m}^{2}\right)$, moderate $\left(20-30 \mathrm{weed} / \mathrm{m}^{2}\right)$, high $(30-40$ weed $\left./ \mathrm{m}^{2}\right)$, and very high $\left(>40\right.$ weed $\left./ \mathrm{m}^{2}\right)$,

\section{5- REFERENCES}

Bulletin of Estimates Agricultural Income, 2015, The 25 , Economic Affair Sector, Arab Republic of Egypt, Ministry of Agriculture and Land Reclamation. 
Ghersa, C.,. Benech-Arnold, R. L, Satorre, E. H. and Martinez-Ghersa. M. A., 2000, Advances in weed management strategies, Field Crops Research, 67 (2): 95- 104.

Gianessi, L. P., and Reigner. N. P., 2007, The value of herbicides in U.S. crop production, Weed Technology 21 (2): 559-566.

Hunt, D., 1983, Farm power and machinery management, 8th Ed. Iowa state Univ., Press Ames, USA. Ames, Iowa, USA: 364-368.

Tekade, M. and Dhaliwal, I. S., 2007, Performance of power operated rotary weeder in sugarcane and maize, Journal of Research, Punjab Agricultural University, 44 (3): 230-233.

Weerasooriya, G. V., Jayatissa1, D. N. and Rambanda, M., 2016, Practical field test on newly designed burial type lowland power cultivator for effective weed control in North-Central Province of Sri Lanka, Tropical Agricultural Research, 28 (1): 107 - 114.

Weide, R. Y., Bleeker, P. O., Achten, V. T., Lotz, L. A., Fogelberg, F. and Melander, B., 2008, Innovation in mechanical weed control in crop rows, http://dx.doi.org/10.1111/j.1365-3180.2008.00629.x., Weed Research 48 (3): 215-224.

الملخص العربي

\section{تطوير عملية العزيق الآلى لمحصول بنجر السكر}

يحيى الحينى"(')، إبراهيم يحيى(")، أحمد ماهر الليثى(") و أحمد فيصل(")

تهدف الدراسة إلى تطوير عملية العزيق الآلى بين خطوط بنجر السكر في المشاريع العملاقة.

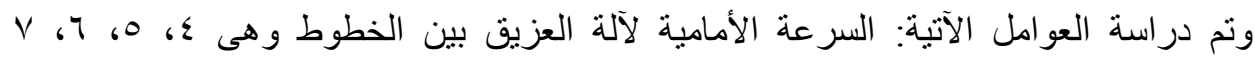

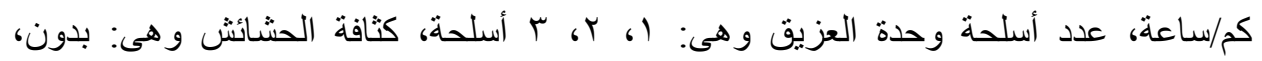

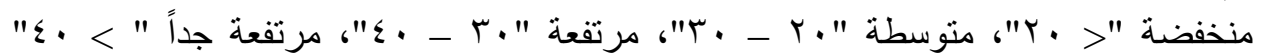

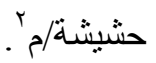

(1) أستاذ الهندسة الزراعية، كلية الهندسة، جامعة أسيوط، (Y)، (؟) أستاذ ورئيس قسم نظم ميكنة

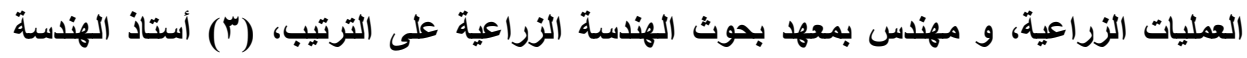
الزراعية، كلية الهندسة الزراعية، جامعة الأزهر بأسيوط. 
وكانت أهم النتائج المتحصل عليها هى كالتالى:

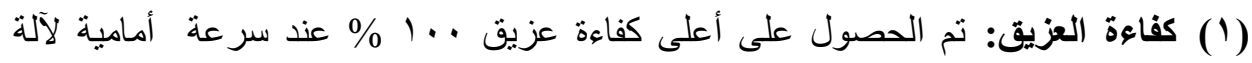

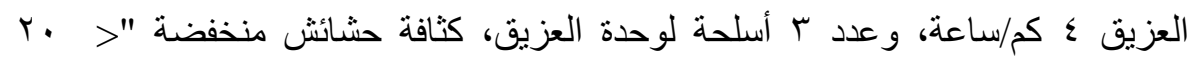

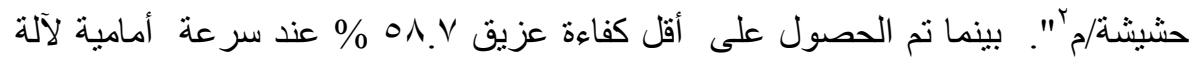

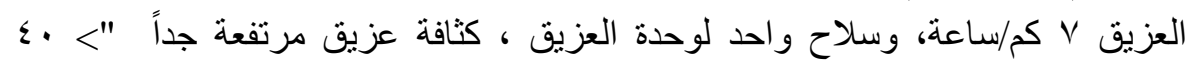

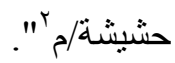

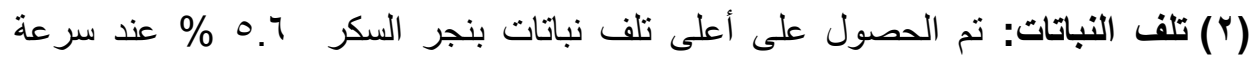

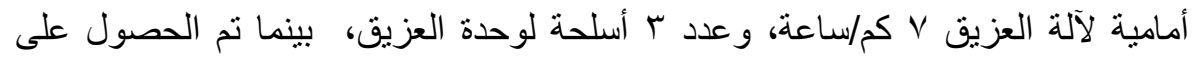
أقل تلف نباتات بنجر السكر 79. وبإستخدام سلاح واحد لوحدة العزيق.

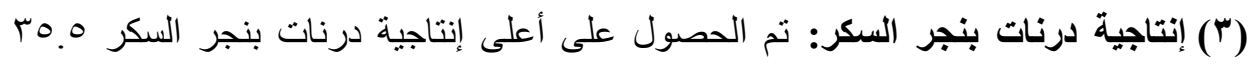

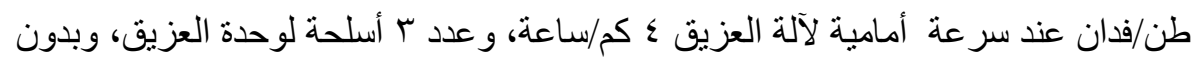

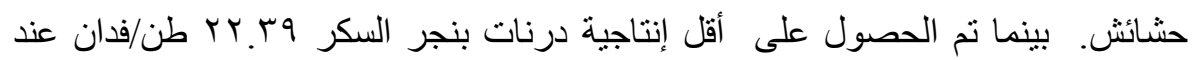

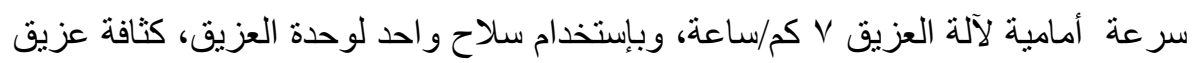

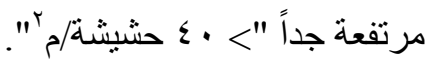

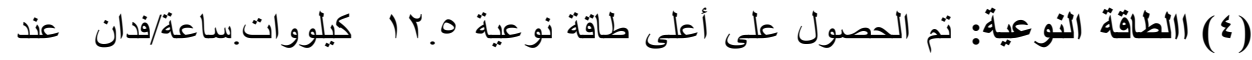

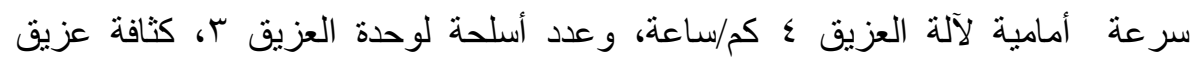

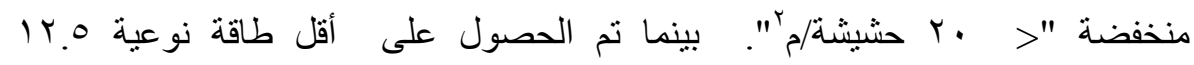

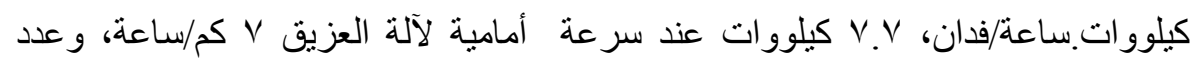

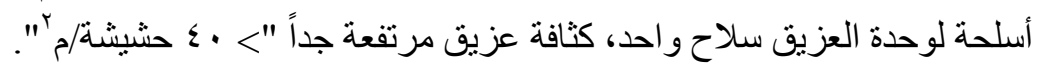

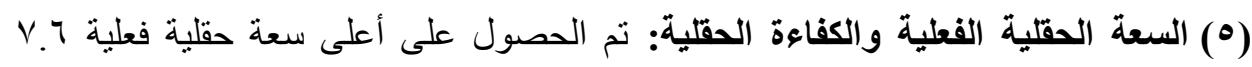

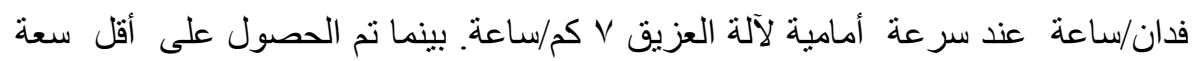

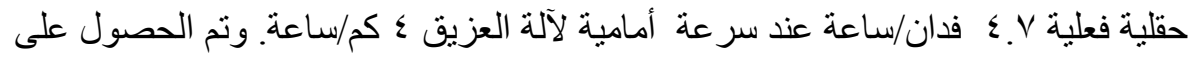

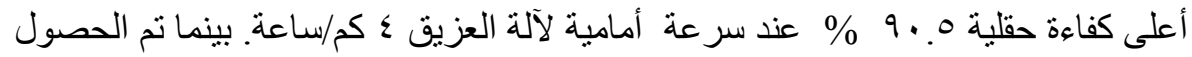

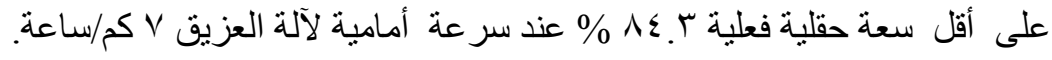

(7) تكاليف الإنتاج وصافى الربح: تكاليف الإنتاج الفعلية لمحصول بنجر السكر المنزرع آلياً

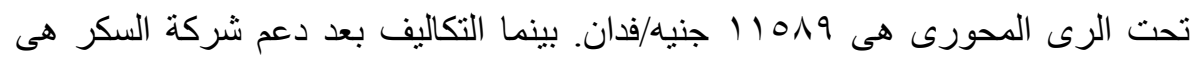

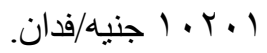




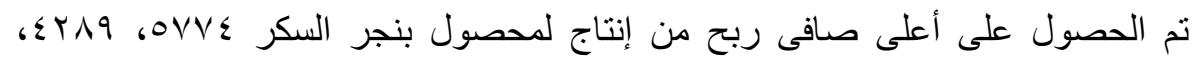

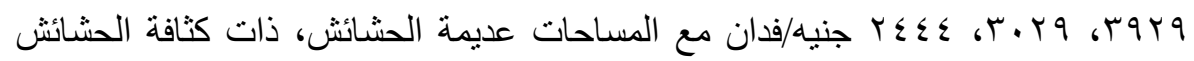

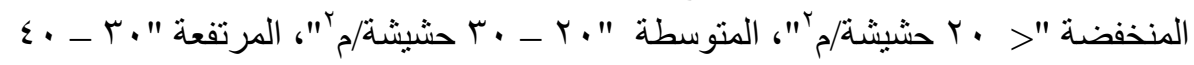

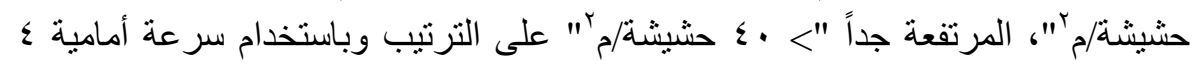

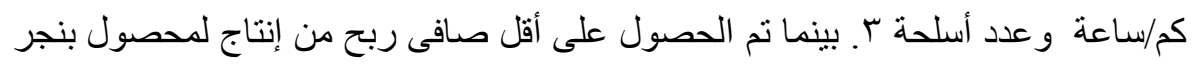

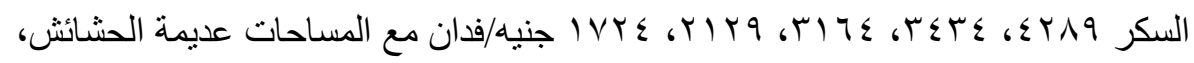

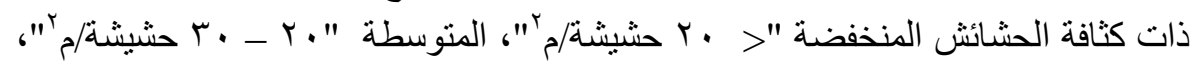

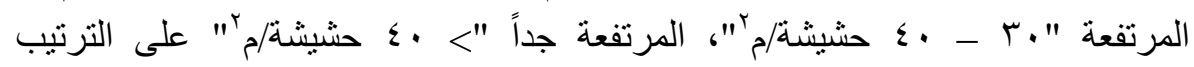

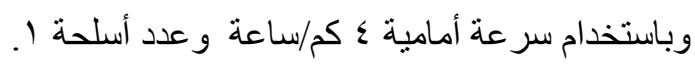

